\title{
HERANÇA FAMILIAR E CULTURAL NA SAGA ROMANTIZADA DO POLONÊS ANTONI DOLĘGA CZERWIŃSKI: TRAÇOS LITERÁRIOS E MÍTICOS PRESENTES NA HEROICIZAÇÃO DA TRADIÇÃO ORAL REFERENTE AO PERSONAGEM HISTÓRICO.
}

\author{
Family and Cultural Heritage in The Romantized Saga Of Polish \\ Antoni Dołęga Czerwiński: Literary and Mythical Traces Present in The \\ Heroicization Of Oral Tradition Regarding Historic Character.
}

Jucelino de SALES

Secretaria de Estado de Educação do Distrito Federal - SEE/DF e Universidade de Brasília -

$\mathrm{UnB}$

disallesart@hotmail.com https://orcid.org/0000-0002-8176-5085

\begin{abstract}
RESUMO: Antoni Dołęga Czerwiński, alcunhado pelos seus descendentes de $O$ polonês, que segundo Jan Magalinski, seria em território goiano "o primeiro imigrante que se tem notícias mais concretas $[\ldots]$ de nacionalidade polonesa e pertencente ao exército napoleônico" (MAGALINSKI, 1984, p. 129), foi um importante herói polonês que deixou prole numerosa no Brasil. Esse lendário imigrante, no final da primeira metade do século XIX, se estabeleceu na outrora Província de Goyaz, numa microrregião atualmente conhecida como Chapada dos Veadeiros, localizada no nordeste goiano, no Entorno do Distrito Federal. O personagem histórico perdurou e perdura na voz oral e na memória coletiva de seus descendentes sob o antropônimo, Antonio Rebendoleng Szervinsk, variante abrasileirada do nome polonês original. $\mathrm{O}$ arranjo mítico disposto e romantizado na memória familiar testemunha a existência histórico-literária do personagem que, obrigado a expatriar-se de sua terra natal e a viver no exílio, funda uma inumerável descendência em terras brasileiras, refundando no Brasil a Polônia, pois é com o topônimo de sua geografia natalícia que nomeia a gleba de terras que ganhara em carta de sesmaria das mãos do Imperador Dom Pedro I. PALAVRAS-CHAVE: História e literatura; Narrativa oral; Mito do herói; Memória familiar.
\end{abstract}

ABSTRACT: Antoni Dołęga Czerwiński, nicknamed by his descendants of $O$ Polonês, who according to Jan Magalinski, would be in Goiás "the first immigrant who is known [...] of Polish nationality and part of the Napoleonic army" (MAGALINSKI, 1984, p. 129), was an important 
Polish hero who left numerous offspring in Brazil. This legendary immigrant, at the end of the first half of the 19th century, settled in the former Province of Goyaz, in a microregion currently known as Chapada dos Veadeiros, located in the northeast of Goiás, in the surroundings of the Federal District. The historical character endured and endures in the oral voice and in the collective memory of his descendants under the name, Antonio Rebendoleng Szervinsk, a Brazilian variant of the original Polish name. The mythical arrangement arranged and romanticized in the family memory testifies to the historical-literary existence of the character who, forced to expatriate from his homeland and live in exile, founds innumerable descendants in Brazilian lands, recreating Poland in Brazil, and with the name of his birth geography that called the land that he had won in a letter from the Emperor Dom Pedro I. KEYWORDS: History and literature; Oral narrative; Hero myth; Family memory.

\section{ENTRE À LITERATURA E A HISTÓRIA: O MITO DO POLONÊS}

No livro História da literatura polonesa, o professor Henryk Siewierski pontua a condição de que em qualquer sociedade que busca suas origens "os mitos e lendas herdados dos tempos remotos, chamados pré-históricos, continuam a fazer parte da história" (2000, p. 15). Em sua obra História e memória, o medievalista Jacques Le Goff resvala na questão dos mitos (genealogias, origens) que se tornam parte da história, no sentido de que certas sociedades buscam a se filiar a um ancestral fundador cujo começo, geralmente, cruza-se a uma origem heroica (2003, p. 55).

Os apontamentos que retomo nesse artigo provêm como continuidade da dissertação de mestrado que defendi há alguns anos atrás, intitulada: Tessituras de memórias no interior de Goiás: a saga do polonês Antonio Rebendoleng Szervinsk [des]fiada no tear do imaginário (SALES, 2014) ${ }^{1}$, narrativa que remontei através de depoimentos orais e investiguei a saga de Antoni Dołęga Czerwiński, alcunhado pelos seus descendentes de o Polonês, que foi um importante herói polonês que deixou prole numerosa no Brasil, conhecido na memória coletiva de seus descendentes sob o antropônimo, Antonio Rebendoleng Szervinsk, variante abrasileirada do nome polonês original.

Sua saga possui muito dos elementos tanto da história, do mito e da literatura. Derivada de uma raiz germânica, a qual se filiam o alemão sagen e o inglês to say, cujo significado primordial retraça a imagem conceitual "dizer" ou provinda do vocábulo da

\footnotetext{
${ }^{1}$ Adissertação encontra-se disponível para consulta no sítio eletrônico da Biblioteca da Universidade de Brasília no seguinte endereço eletrônico: < https://repositorio.unb.br/handle/10482/16634>.
} 
língua gótica saega que significa “o que se diz”, a terminologia saga, segundo o Dicionário Aurélio de Língua Portuguesa, consubstancia como algumas de suas semânticas, o sentido de "Canção heroica ou lendária" ou ainda "História ou narrativa rica de incidentes" (FERREIRA, 2010, p. 1874).

A história deixada por esse ancestral no tecido de sua família trata-se daquilo sobre "o que se diz", ou seja, um "dizer" que permaneceu na memória familiar e que os depoimentos colhidos, manifestaram esse dizer na voz. Como o medievalista Paul Zumthor reflete no seu livro Introdução à poesia oral:

\begin{abstract}
Ora, a voz é querer dizer e vontade de existência, lugar de uma ausência que, nela, se transforma em presença; ela modula os influxos cósmicos que nos atravessam e capta seus sinais: ressonância infinita que faz cantar toda matéria... como o atestam tantas lendas sobre plantas e pedras enfeitiçadas que, um dia, foram dóceis (1997, p. 11).
\end{abstract}

A oralidade é uma ausência que convoca sua presença via voz, ou seja, na narrativa oral. Esse dizer, esse "diz-que", remonta, sobretudo, a uma história ou narrativa rica em incidentes, aqui referendada como sendo a saga do polonês Antonio Rebendoleng Szervinsk que, se não apresenta em sua estrutura sendo uma canção, no entanto, se desenrola como uma canção heroica ou lendária consumada na epopeia Vozes do cerrado (2009), do poeta goiano, também descendente do polonês, Kiko di Faria.

Assim como Aristóteles preconizava n'A Poética, a diferença básica entre poesia (literatura) e história se coloca nesses termos: enquanto esta relata o que de fato ocorreu, aquela narra o que poderia ter ocorrido (ARISTÓTELES, 2017, p. 95); distinção esta que mais que diferir, por outro lado, aproxima, uma vez que, do tempo verbal do que poderia para o que realmente ocorreu, é uma questão de modos temporais. A saga do polonês se coloca nessa dimensão intervalar entrementes a história e a literatura.

Trata-se de uma narrativa oral potencializadora de ficção. Encerrada nesse limite, a saga do polonês é um produto cultural do imaginário social da família Szervinsk e, por isso, um documento social válido como exercício de abordagens, de análise e de interpretação. 


\title{
DO TEAR AO TEXTO: TECENDO A TRAMA DE UMA SAGA
}

\begin{abstract}
Que a gente ficava sabendo? Através de nossos pais, na beira de um fogo. Dentro de uma casinha de palha. De noite iam contar causo. Trabalhava, trabalhava, trabalhava, depois de noite ia... Parava para conversar. Fazer uma pipoquinha no borralho [risos]. Ali, pipoca pipocava e a gente estava escutando pai contar os causos, as histórias dos nossos antepassados. (Rosa Elcides Szervinsk, tataraneta do polonês)
\end{abstract}

Aquiles, filho de Antoni Dołęga Czerwiński, o Polonês, o desbravador que no século XIX se assentou na porção sul da Chapada dos Veadeiros no nordeste goiano do Planalto Central, onde fundou a Fazenda Polônia, na outrora Província de Goyaz, hoje Entorno do Distrito Federal, fabricou artesanalmente um tear. Nesse tear, sua célula gentílica, na manufatura do cotidiano, tecia, com o algodão cultivado em suas próprias terras, as roupas que vestiam e os cobertores com que agasalhavam do frio todo o clã nas funduras do sertão goiano.

O tear, objeto mais do que centenário, resistiu ao tempo e se transformou em memória viva, documento-monumento, dessa história passada e ainda presente no sertão do Planalto Central. Herdado pela anciã de noventa anos, Graciana Alcides Szervinsk, trineta do polonês, encontra-se hoje sob a guarda provisória de Leulízia Herculano Szervinsk, descendente de Heitor, por sua vez, também filho do polonês e irmão de Aquiles. O tear (imagem abaixo) ainda funciona com desenvolta saúde para a tessitura de vestuários, tapeçarias e cobertores, participando ainda hoje da economia familiar. 


\section{FIGURA $1^{2}-$ (PINTURA DE MINHA AUTORIA SOBRE O ANTIGO TEAR FABRICADO POR AQUILES, COMO AFIRMAM SEUS DESCENDENTES).}

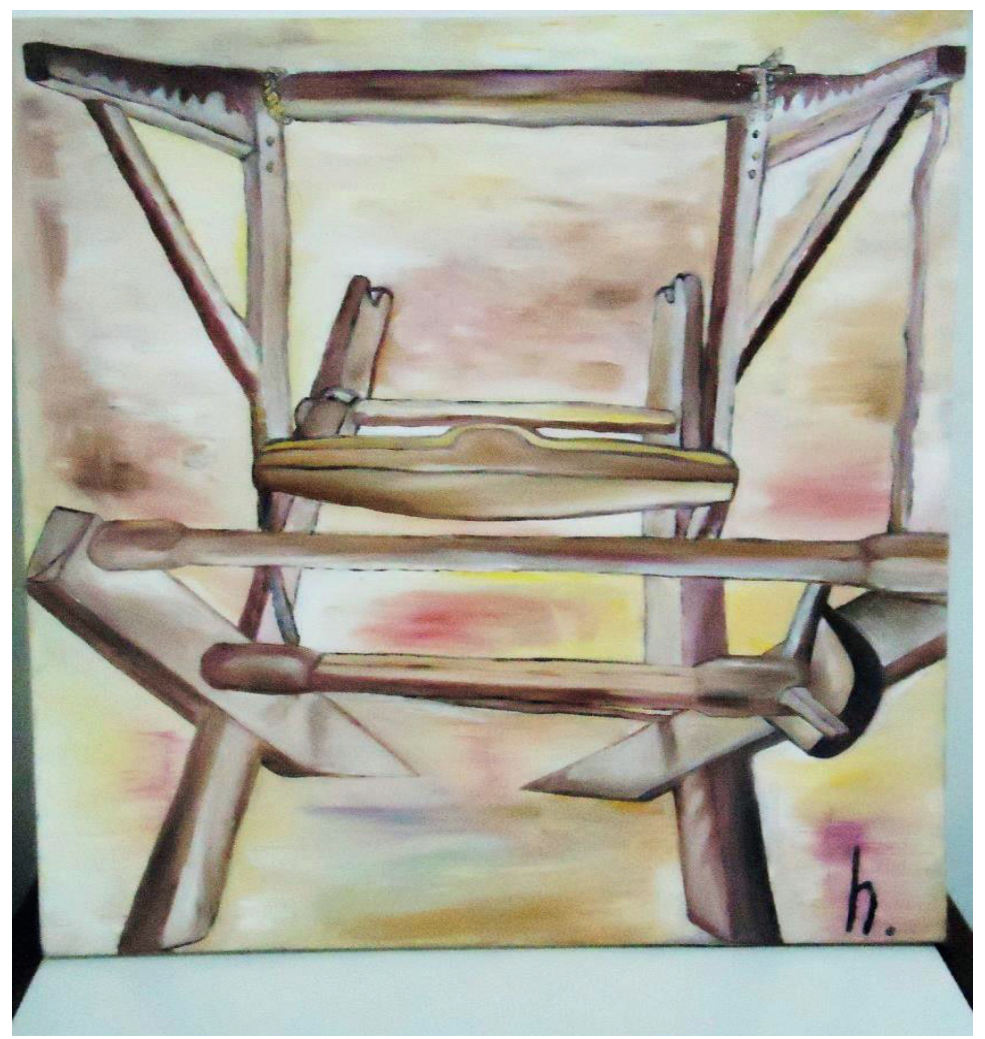

FONTE: O autor (2014)

Nas mãos dessas mulheres, descendentes de Antoni Dołęga Czerwiński - o polonês que semelhante a Ulisses atravessou mares - este tear remete ao artifício de Penélope que [des]fiava com ardil de retardo as intenções casadouras de seus pretendentes, cosendo de dia e desfazendo à noite a mortalha do sogro, engodo que durou os longos anos de sua espera e consolidou sua fidelidade. O mote do tear aparece no epos de Homero, indo Penélope "à roca e ao tear" (HOMERO, 2011, p. 33, Canto I) e, nesse sentido, imagem já consolidada na Odisseia, um dos mais antigos pilares de nossa duradoura tradição literária ocidental.

Conforme aufere o filósofo Cornelius Castoriadis "a história é essencialmente

\footnotetext{
${ }^{2}$ Esta e outras figuras que aparecem no corpo do texto estão sob nossa posse e aparecem inscritas no corpo da dissertação. A imagem acima diz respeito a um tear centenário cujos descendentes afirmam que foi artesanalmente fabricado pelo personagem histórico Aquiles Alcides Szervinsk, filho do polonês Antoni Dołęga Czerwiński.
} 
poiésis [...] criação e gênese ontológica no e pelo fazer e o representar/dizer dos homens" (1982, p. 14, grifos nosso). A poesia/poiésis é personificada pela musa Caliope, a de Bela-Voz, uma das nove filhas de Mnemosine (Memória) e também amante de Ulisses na Odisseia. Sua irmã Clio, a Proclamadora, personifica a própria história. Para o mundo grego antigo a poiésis etimologicamente é fabricação. $\mathrm{O}$ que a vincula diretamente a história conforme a elucidação de Castoriadis.

O tear, fabricação de Aquiles, se coloca numa tessitura encerrada entre a história, o mito e a literatura: poiésis. O tear do imaginário urde a trama da vida..., das vidas derivadas da descendência desses dois irmãos, filhos do polonês, que em solo goiano constituiu prole numerosa (FARIA, 2009), deixando na memória coletiva familiar a narrativa oral de sua saga.

A história dobra-se sobre si própria. Nessa dobra contamina-se com o elemento mítico e torna-se artefato literário. Aquiles e Heitor, filhos do polonês, filhos de uma gesta ao mesmo tempo europeia e brasileira, filhos de uma gesta mítica, ancorados em algum lugar no meio do sertão do Planalto Central do Brasil e no imaginário das pessoas da família Szervinsk (corruptela do sobrenome Czerwiński).

Aquiles e Heitor, os valentes heróis homéricos, antagonistas na lendária guerra de Troia, polarizadores entre duas nações, na fenda entre gregos e troianos. Aquiles e Heitor, dois filhos do polonês, antagonistas na trama da vida, pois também se inimizaram, e vivenciaram uma inimizade histórica presente na memória oral da família Szervinsk, perdendo o conhecimento um do outro, numa briga entre irmãos gerando uma animosidade que dura para séculos sem fim³.

Personagens históricos tingidos com a bruma literária, filhos do polonês, lendário herói mítico, que são ascendentes de prole numerosa, um povo que nas bordas do planalto goiano ultrapassou a mágoa inimizadora desses dois irmãos históricos e sentem o orgulho de serem centenas de folhas, provindas do rizoma de uma árvore comum: o polonês Antoni Dołęga Czerwiński.

\footnotetext{
${ }^{3}$ A inimizade histórica entre os irmãos Aquiles e Heitor, filhos do polonês Czerwiński, foi trabalhada no terceiro capítulo da dissertação, no qual analiso o mitema irmãos inimigos, cuja variável arquetípica aparece ao longo da história da humanidade e o relato de bíblico de Caim e Abel é um dos pilares desse motivo mítico. Um resultado mais concentrado desse análise também se encontra publicado na Revista Nau Literária, da Universidade Federal do Rio Grande do Sul, no artigo Da mitologia à literatura: Heitor e Aquiles presentes na lenda de fundação de uma comunidade rural nas entranhas do nordeste goiano, no Planalto Central do Brasil, disponível para consulta no seguinte endereço eletrônico: $<$ https://seer.ufrgs.br/NauLiteraria/article/view/43586>.
} 


\section{O LENDÁRIO POLONÊS ANTONI DOLĘGA CZERWIŃSKI}

$\mathrm{Na}$ pesquisa de mestrado, investiguei a natureza mitopoética do personagem histórico Antoni Dołęga Czerwiński, alcunhado pelos seus descendentes de o Polonês, que segundo Jan Magalinski seria em território goiano "o primeiro imigrante que se tem notícias mais concretas [...] de nacionalidade polonesa e pertencente ao exército napoleônico" (1984, p. 129). Na investigação, discuti os mitos e as narrativas orais ao redor do ancestral, fundador de uma linhagem de origem polonesa, da qual pessoalmente participo como descendente da quinta geração.

\section{FIGURA 2 - DONA GRACIANA, MINHA TIA-AVÓ, TRISNETA DO POLONÊS, SENDO ENTREVISTADA POR MIM EM 2013.}

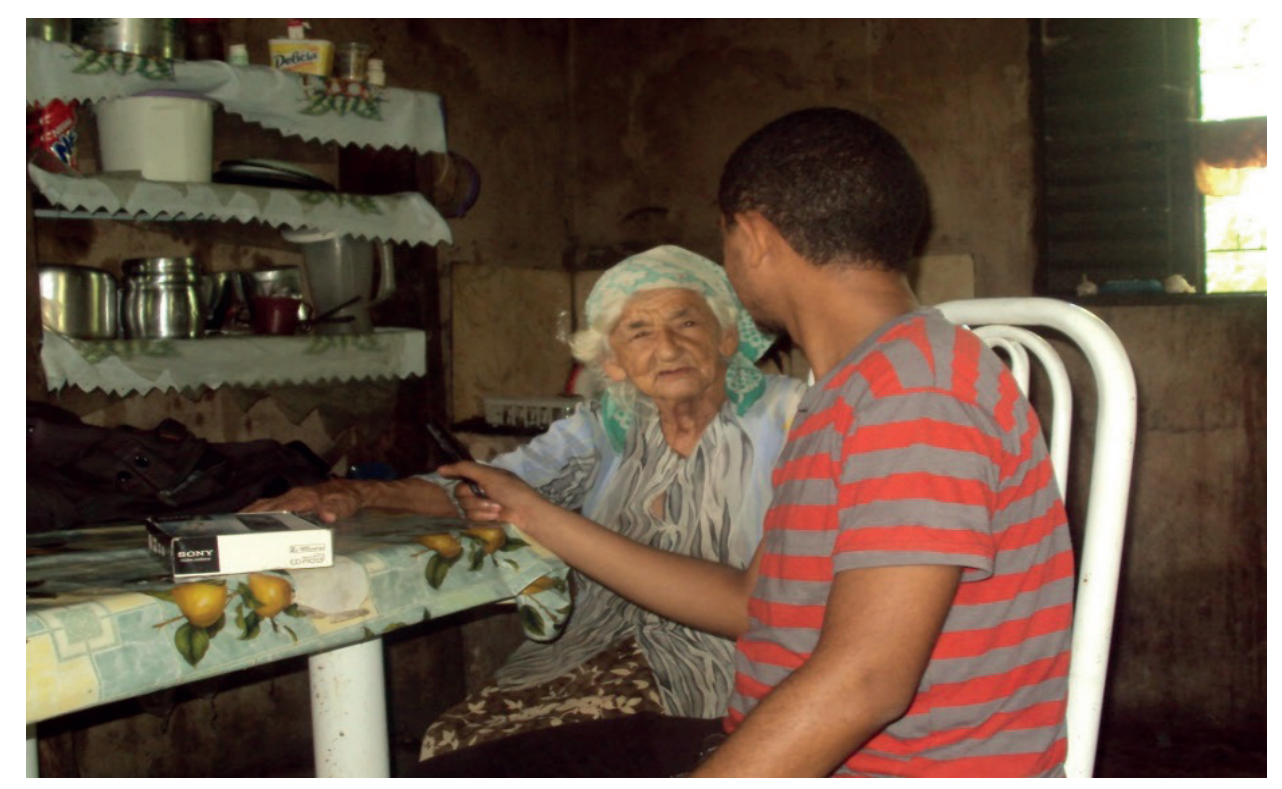

FONTE: O autor (2014)

A historicidade do personagem pode ser comprovada tanto em Magalinski como também nos apontamentos de Antoni Olcha que prefaciou o livro Moje życie w Brazylii (Minha vida no Brasil) de autoria de Władysław Wójcik, uma publicação de 1961. No prefácio, ao aludir à emigração, Olcha tece breves comentários sobre o ancestral:

Os primeiros emigrantes da Polônia procuravam no Brasil, sobretudo, abrigo ante as perseguições da Prússia e da Rússia tsarista. Logo após as guerras Napoleônicas, no estado de Goiás assentou-se o soldado das 
legiões de Dąbrowski, participante da guerra na Espanha, o general Antoni Dolega-Czerwiński ${ }^{4}$ (1961, p. 6, tradução de Natalia Klidzio).

O excerto historiciza tanto o nome quanto a origem do personagem histórico, aponta o motivo de sua expatriação, a busca por refúgio no território brasileiro, além de indicar que era ele um soldado de alta patente, um general, que tanto lutou nas guerras napoleônicas como também era integrante hierarquicamente bem posicionado no exército de Jan Henryk Dąbrowski, general considerado herói polonês por seus esforços na luta pela independência da Comunidade Polaco-Lituana.

Exumando o trecho, podemos inferir que como soldado das legiões de Dąbrowski, o general Antoni Dolega Czerwiński também contribuiu na luta pela independência polonesa e, portanto, se consolida como um herói da Polônia.

Herói que partiu em exílio para o Brasil e, paradoxalmente, deixou conservada na memória familiar não particularmente seus feitos no exército napoleônico, mas os seus feitos fantásticos, com episódios carregados com uma opulência lendária. A lenda tornouse o próprio polonês. Fez-se mito entre os seus pertencentes.

\section{A Consolidação do Mito do Polonês}

O personagem histórico perdurou e perdura na voz oral e na memória coletiva de seus descendentes sob o antropônimo, Antonio Rebendoleng Szervinsk, variante abrasileirada do nome polonês original, provavelmente derivante de um erro cartorial. A condição de um pertencimento identitário e de uma herança cultural evocadores de uma origem ancestral comum solidariza com a mítica travessia do polonês, uma história, em muitos pontos, expressivamente romântica e romantizada no repertório de lembranças de seus pertencentes.

O polonês, impossibilitado de retornar à sua terra de origem, transpôs para a memória familiar de sua linhagem, as marcas de suas errâncias. Provinda do grego, a palavra retorno que se diz nóstos, traz inerente na sua imagem conceitual em um dos campos semânticos o sofrimento de nostalgia, ou seja, o "desejo irrealizado de retornar", que geralmente significa "apenas a tristeza provocada pela impossibilidade de volta ao país", e por isso "nostalgia da terra natal" (KUNDERA, 2002, p. 9). O que se aproxima

\footnotetext{
${ }^{4}$ Trecho original: "Pierwsi emigranci z Polski szukali w Brazylii przede wszystkim schronienia przed prześladowaniami prusactwa i caratu. Tuż po wojnach Napoleońskich w stanie Goias osiedlił się żołnierz legionów Dąbrowskiego, uczestnik wojny w Hiszpanii, gen. Antoni DolegaCzerwiński”.
} 
do conceito português de saudade.

Errâncias que reinterpretou a luz de uma forma mítica elaborada e, de alguma maneira, permaneceram na memória de sua descendência. Impossibilitado de seu retorno à terra natal e, ignaro ao que acontecia por lá, não deixou de exprimir seu sentimento de nostalgia e, consequentemente, sua saudade devotada ao solo pátrio ao nomear um pedaço do sertão do nordeste goiano com o topônimo de sua nação. Em solo brasileiro, o personagem histórico (re)fundou simbolicamente sua Polônia.

\section{FIGURA 3 - RUÍNA DOS ALICERCES DA ANTIGA SEDE NA COMUNIDADE FAZENDINHA NO MUNICÍPIO DE ÁGUA FRIA DE GOIÁS, ONDE MOROU O POLONÊS ANTONI DOŁĘGA CZERWIŃSKI COMO AFIRMAM SEUS DESCENDENTES.}

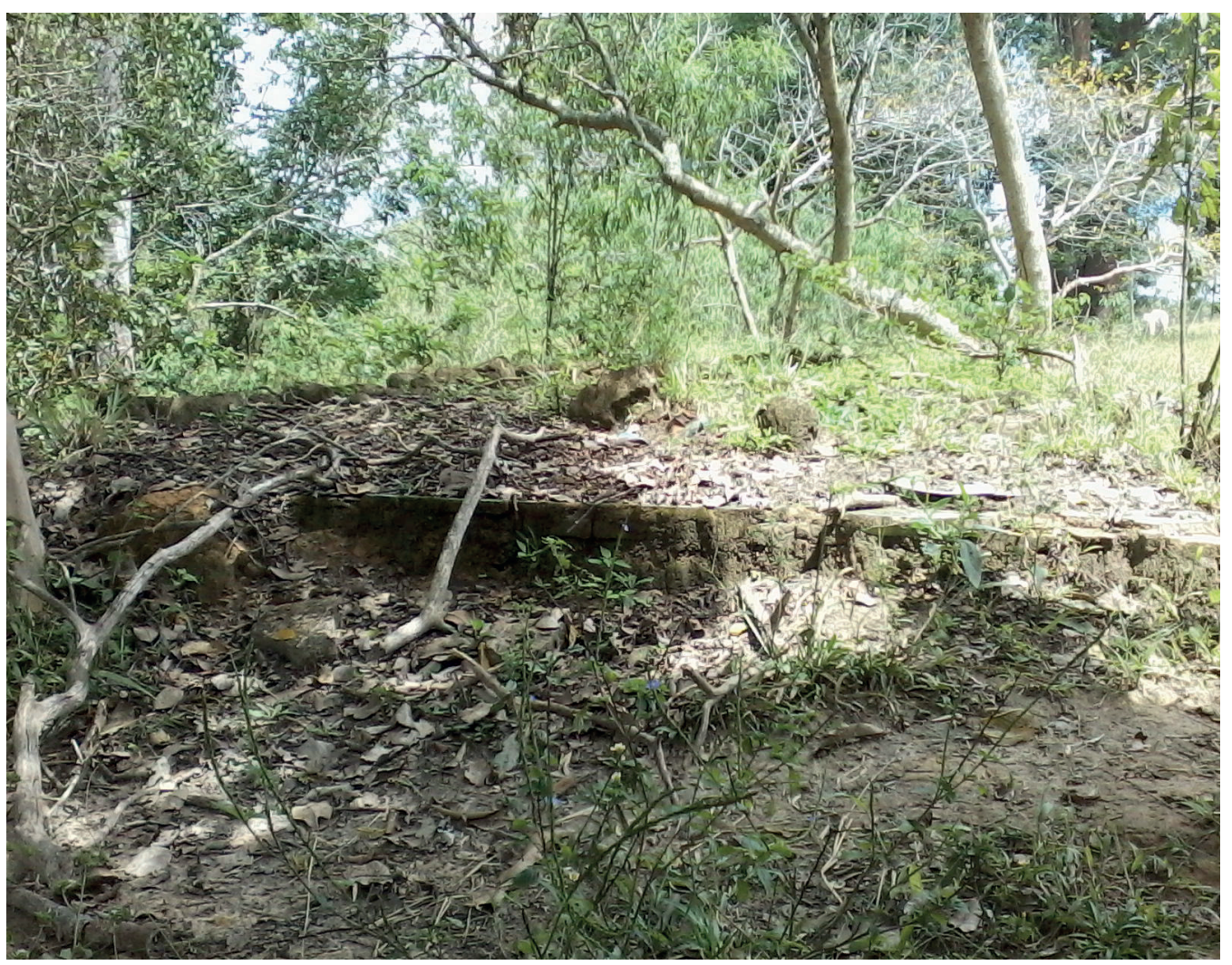

FONTE: O autor (2014)

O personagem histórico deixou os rastros de seu heroísmo ao marcar a memória coletiva da família Szervinsk com impressões de suas errâncias, no narrar de episódios insólitos e mirabolantes que teimam em permanecer no imaginário familiar. O polonês, nessa nova terra, se reconciliou consigo mesmo, tornando imortal, de alguma forma, a 
memória que resiste sobre si para o passado e para o futuro. Afinal, como diz Milan Kundera "o retorno é a reconciliação com a finitude da vida" (2002, p. 11).

São cinco episódios fantásticos cujas marcas mnemônicas permanecem com traços de força maior no imaginário da família Szervinsk, e nos quais pode-se perceber os traços de heroísmo que orbitam em torno do lendário polonês, tais como, sua audácia, sua astúcia, sua bravura, sua sorte:

1. O Polonês encontra-se numa guerra em sua província natal, a Polônia. Para safar-se da morte, abre a barriga e retira as vísceras de um animal de cavalaria e, em seguida, se esconde no interior da carcaça, sugerindo o mitema do cavalo de Troia ou ainda a narrativa bíblica Jonas e a baleia;

2. Na fuga, o Polonês, em companhia de um amigo, foge de soldados que os perseguem em sua própria pátria. A espada do amigo parte-se ao meio. $\mathrm{O}$ Polonês, o melhor espadachim, recebe por baixo das pernas a espada quebrada do amigo. Ambos conseguem vencer os adversários e fugir, sugerindo o mitema das grandiosas batalhas dos romances de cavalaria, a exemplo do grande guerreiro Rolando e sua espada durindana;

3. O Polonês, em determinado momento, lança-se ao mar. Atravessa o oceano ou um braço do mar a nado, evocando a memória de literatura perlustrada na estrutura arquetípica da Odisseia de Homero que narra o retorno de Ulisses, navegando pelos mares desconhecidos;

4. Já em terras brasileiras, o Polonês é capturado por uma tribo antropofágica. Ele próprio consegue sobreviver a essa desventura com o truque de se colocar fogo no que parecia ser na água, mas que, na verdade, é álcool, segundo uma das versões, - inclusive, artifício usado pelo Anhanguera, mito fundador da província de Goyaz. Numa outra versão, um padre intervém prometendo escambo, conseguindo assim salvar o personagem histórico de seu destino manifesto. O Polonês escapa do sacrifício canibal.

5. Chega a Minas Gerais, no interior das terras brasileiras, apaixona-se e casa-se com uma moça de Piumhi, chamada Umbelina Alcides, tendo com ela vários filhos. Vai até o interior de Goiás onde se assenta na Fazenda Polônia. Dois de seus filhos se destacam, os irmãos Aquiles e Heitor, pois lhes são dados nomes de inimigos famosos e formam, a partir daí, dois clãs opostos na família, que semelhantes aos heróis opositores da Guerra de Troia que, misteriosamente, talvez até por uma ironia intertextual, ambos os irmãos históricos se inimizam 
em vida, tornando-se tal qual Caim e Abel, irmãos inimigos, conforme afirmado na memória oral dos descendentes.

Em relação ao primeiro episódio, por exemplo, Maria da $\mathrm{Cruz}^{5}$ nos relatou essa memória:

Ele se escondeu na barriga de um animal porque estavam todos guerreando e não tinha mais nada para se esconder. Então, vinha aquela multidão para matar, e ele se fingiu, passou por morto. E naquela aflição tinha um cavalo. Ele furou, matou ele. O cavalo já estava morto. Ele só arrancou o bucho dele e escondeu dentro dele para não ser morto naquela hora da aflição dele [...]. No momento em que estava acontecendo a guerra, a matança. O cavalo estava morto, ele furou a barriga do cavalo, arrancou o bucho, escondeu lá, para ele passar e não verem ele (ENTREVISTA 4, 2013, p. 3, grifos meus).

Manoel Carvalho, outro descendente e colaborador, corrobora o mesmo episódio, com poucas variações. Não era um cavalo, e sim um burro. De toda maneira, referem-se a um animal da família dos equinos:

Sei dizer que: diz que ele atravessou... Olha, como é que era, diz que ele tinha atravessado? Que ele escondeu até dentro da barriga de um burro. [...]. Pois, escondido dentro da barriga de um burro [...] para se salvar da guerra... (ENTREVISTA 5, 2013, p. 3)

Não obstante, encontramos o mesmo episódio na epopeia Vozes do cerrado. Como relatam os versos do poeta Kiko de Faria, que narrou a história em versos:
Só ele e a montaria
Pelos soldados cercados
A sacrificar o cavalo
Se viu ele obrigado
Matou o pobre animal
E seu ventre abriu
Enterrou suas entranhas
E em seu ventre se inseriu
Ajeitou o animal morto
Para esconder a fissura
E escondido em seu ventre

\footnotetext{
${ }^{5}$ As entrevistas encontram-se disponíveis nos anexos da dissertação, no link: $<$ https://repositorio. unb.br/handle/10482/16634>.
} 

Aguentou a desventura
Ouvindo seus inimigos
Rosnando bem ao seu lado
Sentiu que ali a morte
O havia derrotado
Mas como sempre afirmava
Deus a ele foi fiel
Dispersou seus inimigos
Que rodeavam o corcel
Seguindo a esmo a busca
Deixou ali o procurado
Que no bucho do cavalo
Havia se entrincheirado (2009, p. 35-36).

Trata-se enfim de um episódio insólito e mirabolante que circula no imaginário familiar. É evidente que o episódio goza da possibilidade de marcar-se como um fato real: um guerreiro em apuros, diante da morte iminente no campo de batalha, vê no fingimento de sua própria morte uma saída para salvar sua vida. Acomete-lhe a ideia de extrair as entranhas de uma das montarias já mortas por ali e se esconder no ventre do animal. $\mathrm{O}$ tamanho da pessoa, nesse caso, deve coincidir com o espaço desse refúgio que possui para ocultar-se, além de uma série de outros fatores coincidirem para que nada dê errado nessa dissimulação e, entre eles, o fator sorte.

Sobre o segundo episódio, Maria da Cruz em suas palavras, descreveu-nos que:

Passando daí que ele se escondeu. Ele fugiu mais um amigo para vim, para sair fora do país dele, para sair fora da guerra. Aí, quando ele estava passando num, quer dizer, eles dizem uma ponte, ninguém viu ninguém sabe. Uma ponte para entrar numa embarcação. Aí, esse povo vinha guerreando. Ele estava com o amigo dele. Um encostou as costas no outro. Eles começaram a guerrear. Ele guerreava. Ele matava quem vinha de frente. $\mathrm{O}$ amigo dele matava quem vinha de trás. Aí, eles iam rodando e matando, rodando e matando. Inclusive, a espada do amigo dele quebrou. [...]. Ele jogou a espada dele para o amigo dele. E o amigo dele passou a espada dele. $O$ toco de espada por baixo das pernas. Ele pegou e derrubava só com um toquinho de espada (ENTREVISTA 4, 2013, p. 3, grifos meus).

O insólito aparece mais uma vez. Com o dorso encostado um no outro, eles iam rodando e matando, rodando e matando. O Polonês recebeu o toco de espada por baixo das pernas. Ele pegou e derrubava só com um toquinho de espada. Trata-se de um fato extraordinário, narrado na voz de Maria da Cruz, potencializado com a roupagem 
de um fenômeno natural. Cabe a pergunta: como um guerreiro com a metade de uma espada, ajudado só por mais um companheiro, consegue eliminar todo um grupamento de soldados?

Posteriormente, Escolástico Damacena de Salles destrinchou-nos o mesmo conjunto de fatos com poucas variações:

Eu não sei o que aconteceu. Ele fez uma coisa lá e ele precisou de correr. Eles tinham que passar uma ponte, e na ponte o povo estava vigiando. E eles encostaram. Nesse tempo, eles brigavam de espada. Ele encostou a cacunda de um na cacunda do outro. E os que vinha[m] de um lado, eles: espada! E os que vinham do outro, eles: espada! Pra móde ${ }^{6}$ passar. Até passar e saiu do outro lado. [...]. Tinha ele e outro. Eles eram dois. Eles dois brigando de espada. E ainda assim: a espada de um quebrou. E o outro era mais danado e foi falou: "Ó, aqui toma a minha boa, dê cá o toco aqui". E ele deu por entremeio as pernas e pegou o toco. E o outro com a espada boa. E ele com o toco cortando gente até passou. [...]. Que eles atravessaram de cacunda encostada. E uns que vinham de um lado, de bichada. E outros que vinham do outro: espada. Foi a hora que a espada de um quebrou, e o mais danado falou: 'Ah, toma o toco da minha e tome a minha que é boa. De cá o toco para cá. E se você está com medo, você fica com a espada boa' (ENTREVISTA 7, 2013, p. 2-3, grifos meus).

Assim como Maria da Cruz, Seu Escolástico relata um episódio em que o Polonês e um amigo, encurralados pelos soldados inimigos na travessia de uma ponte, duelam com os adversários e a espada do amigo parte-se no meio. O Polonês reclama a espada cindida do amigo e altruisticamente cede-lhe a sua. Ambos atravessam a ponte com as "cacundas" (costas) encostadas, batalhando com o inimigo até se safarem totalmente da enrascada.

Essa força colossal e desmensurada é própria do herói acometido pelo espírito da bravura desde Atlas e Sansão. Condição comum à psicologia dos heróis épicos que aguerridos batalham com ânimo, destemor, denodo e intrepidez, revelando grande coragem, habilidade, proeza e façanha diante do inóspito. Essa marca, a bravura, remetenos ao espírito de um ser que perante as condições desastrosas não teme e nem titubeia, revelando que possui energia, força, vigor e resistência para encarar o adversário mesmo desproporcional e derrotá-lo, ainda que se trate de uma situação claramente incontornável.

No que tange ao terceiro episódio, a colaboradora Graciana Alcides Szervinsk

\footnotetext{
${ }^{6}$ A expressão [pra móde] é um neologismo advindo da expressão [por mó de] que significa por causa de, pela maneira de, pelo modo de.
} 
relembra que "ele veio desertando de uma guerra. Passou no mar. Passou no mar só com as espadas. Saiu cá no Brasil" (ENTREVISTA 1, 2013, p. 4). Ademais, assevera que para fazer essa travessia o Polonês "passou de nado no mar. Passou de nado no mar. Foi em nada não. Foi de nado (ENTREVISTA 1, 2013, p. 7, grifos meus), e reitera "porque ele passou um braço do mar. Que tem os galhos, não é? Ele passou no braço do mar, de nado. E saiu cá no Brasil” (ENTREVISTA 1, 2013, p. 7). Segundo o relato de Graciana, não atravessou nem de barco nem de navio pois "ele era forte. Por isso, quando uma gente briga um com outro, a gente fala: "Ó, está puxando o Polonês" [risos]" (ENTREVISTA 1, 2013, p. 7, grifos meus).

O extraordinário surge na voz da trineta de Antoni Dolęga Czerwiński. A colaboradora afirma que o personagem histórico atravessou o mar foi em nada não. Foi de nado. Depois sutilmente comprime a hipérbole relatando que se tratava de um braço do mar. Mesmo assim, ele atravessou boa parte do mar a nado, até que saiu no Brasil. E a colaboradora dá-nos uma pista que explica o arrojo e o atrevimento do herói em enfrentar o oceano com a ousadia de seu nado: "Ele era forte". Essa condição, diz respeito, de alguma forma, à força desmensurada da qual tratamos ao discutirmos a bravura do herói.

Além disso, a entrevistada sugere pistas a respeito de uma predisposição genética que permaneceu no seio familiar e que remete a essa bravura simbolizada pela saga do Polonês, ao potencializar que "quando uma gente briga um com um outro, a gente fala: 'Ó, está puxando o Polonês"'.

O riso da colaboradora, esse gesto manifesto e a referência de que aquele que nasce com a condição de bravura na família é gestado com esse aspecto comportamental porque puxou traços da psicologia do personagem histórico, conformam a razão de que a identidade familiar se vincula ao pertencimento genealógico.

Assim como a bravura do Polonês, sua audácia perante o desafiante oceano simboliza não apenas sua afoiteza diante dos perigos da vida, como também demonstra, por meio da memória oral, a vinculação de sua estirpe à ousada história de sua travessia.

Há algo de original que recorta a saga do Polonês. Sob uma estrutura arcaica e predisposta no inconsciente manifesto da humanidade - o motivo do herói - a saga desse personagem histórico reabsorve essa estrutura simbólica, a desenvolve na experiência comunal, tornando o espaço social desse conjunto familiar habitado por um arranjo de fatos insólitos, que internamente transparecem como normais e, além disso, alimentam e organizam as experiências desse corpo social.

O jogo simbólico, proporcionado pelo Polonês no "contar" aos seus descendentes, e o "recontar" do mesmo conjunto de episódios através das gerações traz em si, a travessia 
do herói. A virtude final trata-se, nessa estrutura formal, de alcançar o resultado de vitória frente ao inóspito e dificultoso e, assim, significar o espírito de astúcia, bravura e audácia do herói.

A lembrança e rememoração desse conjunto de fatos insólitos e mirabolantes no seio da família Szervinsk tornou-se uma tradição que se opera como o fio que a liga com o seu passado, uma vez que recupera a imagem de um passado grandioso. Essa imagem é uma invenção que, suspeitamos, foi premeditada pelo próprio personagem histórico, o Polonês. Como Maria Inés Mudrovcic afirma “o que denominamos memória coletiva de um grupo é um discurso narrativo que tem como sujeito esse mesmo grupo e que tenta dar sentido a eventos ou experiências relevantes de seu passado" (2009, p. 105).

Nesse limite, trata-se de uma tradição inventada no sertão do nordeste goiano, quando lá o Polonês se assentou, mas que ressalta uma continuidade com a antiguidade helênica e a tradição grandiosa de uma origem lendária, cujo repertório de elementos (conjunto de mitemas) evoca uma cadeia de relações através da linguagem elaborada do mito.

Pai comum, a partir do qual se forma uma comunidade particular, isto é, uma linhagem: parece ser esse o combustível que remete para uma mesma origem as relações antropológicas derrogadas nos membros desse conjunto familiar: a história mítica do polonês fundador da linhagem Szervinsk.

O mito do Polonês, transmitido numa forma oral, diz respeito a um conjunto de mitemas em que na lógica oculta de seus sentidos, relata uma série de acontecimentos ocorrida no tempo primordial, o tempo em que o Polonês na moldura do herói começou a ser. Investido com a psicologia do herói, o Polonês sobrevive como imagem forte e presente na memória coletiva de seu arranjo familiar. Assim, seu mito dá forma a um tempo do princípio e como narrativa de criação funda a ficção de uma origem ao produzir a identidade heroica desse personagem histórico para uso histórico, cultural e identitário dos seus descendentes.

\section{A Fazenda Polônia: Pedacinho da Polônia no Coração do Brasil}

O arranjo mítico disposto nos episódios mirabolantes, romantizado na memória familiar, testemunha a existência histórico-literária do personagem que, obrigado a expatriar-se de sua terra natal e a viver no exílio, funda uma inumerável descendência em terras brasileiras, refundando aqui a Polônia, pois é com o topônimo de sua geografia 
natalícia que nomeia a gleba de terras que ganhara em carta de sesmaria ${ }^{7}$.

A respeito da concessão da sesmaria, Antoni Olcha sublinha que,

O Imperador de Brasil Dom Pedro I concedeu-lhe uma considerável porção de terra. A Fazenda a qual fundou, até os dias atuais, chamase "Polônia". Os descendentes de Czerwiński são mestiços índiospoloneses, que já falam somente em português, ainda assim, guardam a memória da origem polonesa $^{8}$ (1961, p. 6-7, tradução de Natalia Klidzio).

De fato, é inegável a força do mito do Polonês. Todo e qualquer indivíduo que descende dessa linhagem se orgulha íntima e intensamente por possuir no dorso mais profundo desse tronco o sangue polonês. E mesmo que não falemos polonês, Antoni Dołęga Czerwiński tornou-se símbolo de um orgulho desmesurado, uma hybris potente conservada na memória familiar.

Todavia, vale uma ressalva em relação ao apontamento étnico. A linhagem não apenas comporta a miscigenação entre o elemento indígena e o componente polonês, mas goza de uma forte hibridação étnico-cultural, incorporando também a elementaridade negra. A célula gentílica da qual provenho, a exemplo, misturou o sangue polonês com o sangue negro.

Como oficial da Guarda Imperial do Imperador Dom Pedro I, por mérito de seus serviços, Antoni Dołęga Czerwiński, recebeu uma carta de sesmaria para desbravar os rincões longínquos do sertão da Província de Goyaz. Nesse território, em 1848, registrou suas posses, dando legitimidade à Fazenda Polônia que fundara.

Os testemunhos de alguns de seus descendentes marcam, com incisão, não somente a origem natalícia desse personagem, mas também a reverberação do topônimo com que nomeou a fazenda. Escolástico Damascena de Salles declara que "ele era

\footnotetext{
${ }^{7}$ As cartas de sesmarias correspondiam à distribuição colonial de terras na colônia com legislação própria e foi uma das formas que regulou entre os séculos XV e XIX a cessão de terras no Brasil, com variação em suas extensões, com obrigações a serem cumpridas pelo sesmeiro no caso do alcance dessa outorga. Segundo o historiador Francisco Eduardo Pinto, "As cartas de sesmarias são documentos de grande importância para a compreensão da história agrária no Brasil" (2011, p. 33). No caso do polonês Czerwiński, é um importante dado histórico para a compreensão da ocupação agrária do nordeste goiano do Planalto Central.

${ }^{8}$ Trecho original: "Dostał on spory szmat ziemi od cesarza brazylijskiego Don Pedra I. Fazenda, którą założył, do dzisiejszego dnia nazywa się „Polonia”. Potomkowie Czerwińskiego są mieszkańcami indiańsko-polskimi, mówią już tylko po portugalsku, jednakże w tym rodzie żyje pamięć polskiego pochodzenia."
} 
polonês da Polônia e foi, possuiu essa fazenda e pôs o nome de Polônia, lá do país dele" (ENTREVISTA 7, 2013, p. 3). Também João Luís da Silva, outro descendente do Polonês, corrobora: "Polônia. Inclusive, dividiu daqui da Serra Geral, que é Montes Claros para cá, Polônia para lá. Diz que essa comarca, diz que foi ele que fez" (ENTREVISTA 2, 2013, p. 4). Manoel Carvalho Ramos ressalta que o Polonês "registrou a Fazenda Polônia daí de perto de São João [D’ Aliança] até lá na Serra da Piedade" (ENTREVISTA 5, 2013, p. 4).

A [Fazenda] Polônia não só existe como espaço demarcado na voz testemunhal dos descendentes de Antonio Rebendoleng Szervinsk (Antoni Dołęga Czerwiński), como também possui materialidade documentada. O documento datado dos idos de 1848 (figura abaixo), sintomaticamente dois anos antes da famosa "Lei de Terras" no Brasil (conhecida como a lei ${ }^{\circ} 601$ de 18 de setembro de 1850) e que foi registrado na Comarca de Cavalcante, circunscrição à qual, vários municípios do nordeste goiano estavam subordinados à época, prova a existência da fazenda, onde são citados, ainda que com erros nas grafias de seus nomes, o Polonês e a esposa: "Umbelina de Szeminoka casada com Antonio de Szeminoka d[á] para registro dessa Villa e termo a fazenda POLONIA no município de Cavalcante, apariada desde [mil oitocentos e] quarenta e seis com criação e alguma cultura além de benefícios e seos 12 filhos cujos três jásão maiores [...]”.

FIGURA 4 - DOCUMENTO CARTORIAL DATADO DE 18489, “ACHADO” NO CARTÓRIO DE REGISTRO DE NOTAS E OFÍCIOS DO MUNICÍPIO DE SÃO JOÃO D’ ALIANÇA - GO.

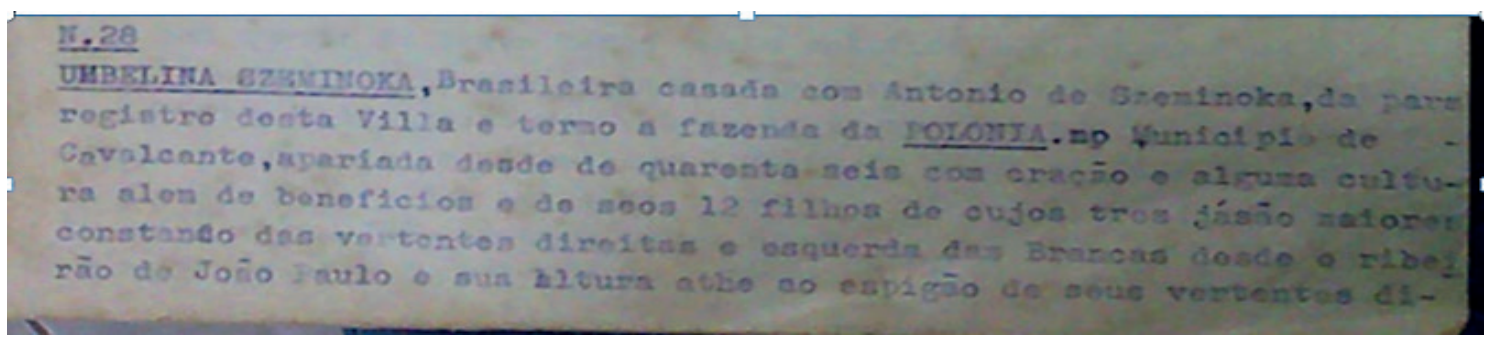

\footnotetext{
${ }^{9}$ Transcrição do documento: "UMBELINA SZEMINOKA, Brasileira casada com Antonio de Szeminoka, da para registro desta Villa e termo a fazenda POLONIA. no Municipio de Cavalcante, apariada desde quarenta e seis com criação e alguma cultura alem de benefícios e de seos 12 filhos de cujos três jásão maiores constando das vertentes direitas e esquerda das Brancas desde ribeirão de João Paulo e sua altura athe ao espigão de seus vertentes direita e sua altura, da Chapada do Soares desde altura do João Paulo entre os córregos do Corrente e expigão das vertentes esquerda do S. Lourenço e Brancas tendo em terras a treis mais ou menos de cumprimento mede quatro e na mesma forma de largura hua légua. Umbelina Szermincha-Antonio de Szerminka. O Pe. Benicio Thomaz de Bastos.”.
} 


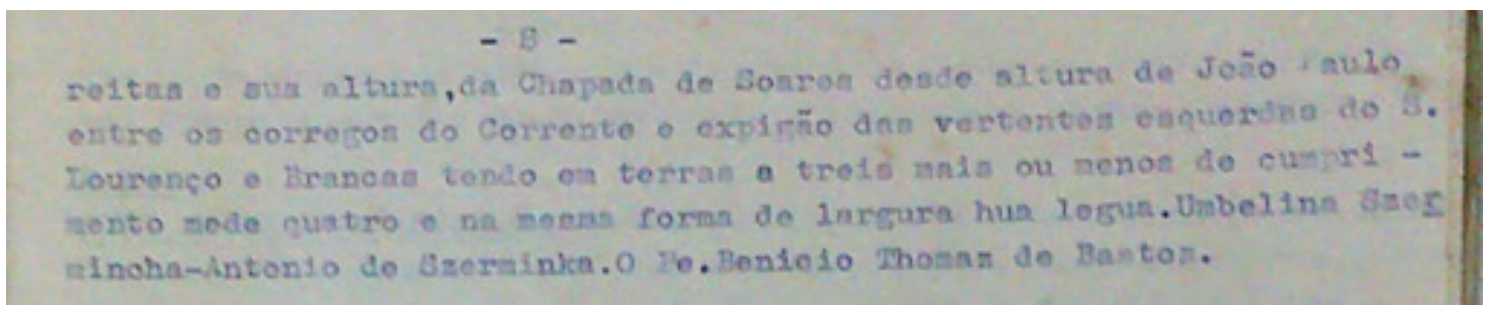

FONTE: O autor (2014)

Salientamos que a prova documental, para o trabalho historiográfico, é um elemento preponderante de análise teórica e construção textual. Conforme Paul Ricoeur declara em relação à investigação documental "os documentos só falam quando lhes pedem que verifiquem, isto é, tornem verdadeira, tal hipótese" (2007, p. 188). Como o filósofo exprime "torna-se assim documento tudo o que pode ser interrogado por um historiador com a ideia de nele encontrar uma informação sobre o passado" (RICOEUR, 2007, p. 189).

Como pode ser lido no documento cartorial disposto na ilustração acima, as informações ali contidas tornam-se ferramentas fundamentais para compreendermos como esse polonês ditou o ritmo de suas vivências e experiências em terras do sertão do nordeste goiano.

O topônimo da antiga Fazenda Polônia grafado no documento em letras garrafais e presente na memória coletiva de seus descendentes, não deixa quaisquer dúvidas no que diz respeito à condição real desse espaço marcado com o nome da pátria desse europeu que nas primeiras décadas do século XIX, fugindo de conflitos bélicos, aportou nas terras do Novo Mundo e com espírito desbravador incursionou ao interior do Brasil até se assentar na região do nordeste goiano, na antiga Província de Goyaz, hoje conhecida nacionalmente como "Chapada dos Veadeiros".

Se o Polonês, de fato, premeditou uma origem mítica para a gesta de sua gens, ao nominar as terras que desbravou e adquiriu no Planalto Central com o nome de sua terra natal Polônia, de toda maneira, pela repercussão que permanece não só no seio familiar, mas o sentimento de furor provocado em todos aqueles que passam a conhecer os episódios insólitos de sua saga, na medida em que os episódios narrados estão organizados sob uma moldura mítica, fazem esse evento histórico adquirir a proporção de uma plataforma estética, sobretudo, literária.

Lastro factual que o poeta Kiko di Faria, no longo poema com traços de epos, Vozes do cerrado, entoa, afirmando a vasta tessitura dessa genealogia, "Gente de todos 
os credos/Toda classe, toda cor/Extensão do velho Rebendoleng/Que aqui se eternizou" (2009, p. 58).

Ascendente dessa extensão, o Polonês marcou com sua origem e com sua saga a psicologia do seu povo, eternizando-se, como o poeta ressalta, na memória coletiva de todos aqueles que reclamam para si a filiação dessa gesta:

O velho Rebendoleng

Se fez como o grão de milho

Morreu pra gerar outros grãos

Uma multidão de filhos

Seus descendentes fecundos não cessam de aumentar

São muitos que já nasceram

Que não se pode contar

Casando e miscigenando-se

Mudaram o nome civil

Porém carregam nas veias

De Antonio o sangue febril

É uma história tão bela

Que muita gente não viu

Pedacinho da Polonia

No coração do Brasil (FARIA, 2009, p. 57, grifos meus).

Na expressão Pedacinho da Polônia no coração do Brasil, o bardo evoca e reclama a fixação desse centro móvel que não deixa de ser as origens, esse centro, cujo ponto fixo se moveu transplantado da Europa, vindo reclamar seu começo e recomeço no centro do nosso país. Como expõe o arqueólogo do saber, Michel Foucault, “a origem está sempre antes da queda, antes do corpo, antes do mundo e do tempo; ela está do lado dos deuses, e para narrá-la se canta sempre uma teogonia" $(1979$, p. 18).

É esse começo, advindo de uma teogonia, de uma narração da gesta dos deuses, do feito dos heróis, que o bardo, na posição também de genealogista, entoa, dando voz às vozes do cerrado, a esse povo do sertão do nordeste goiano do Planalto Central.

Kiko di Faria busca nessa temporalidade distante, através da palavra poética, um princípio inaugural que se esquiva até naufragar-se no tear da memória. Com esse gesto de demarcar o espaço da saga do Polonês em território brasileiro, ele ressalta e dignifica a amplitude dessa tessitura genealógica, cuja plenitude é, com efeito, a sobrevalorização desse espaço circundado pela antiga Fazenda Polônia. 
O acontecimento perdido imagina um começo na voz do poeta, busca uma imagem remota que remonte a uma origem mítica. Ao narrar nesse canto épico não só a ascendência, mas também descrever a genealogia dessa gesta ancestral, os dois ramos principais dessa árvore primordial provindos dos irmãos Heitor e Aquiles e, por sua vez, tecer o jogo familiar entre os filhos, netos, bisnetos e etc. desses dois irmãos, nessa tessitura familiar, o poeta Kiko di Faria realiza um trabalho que se aproxima consideravelmente da arte dos antigos griôs africanos, uma espécie genérica de historiador generalista responsável pela transmissão da tradição, saberes e genealogias antigas (BÂ, 2003).

Conforme o historiador Jacques Le Goff assevera, existe uma predisposição na psicologia dos povos para se filiar a uma origem que seja, sobretudo, grandiosa: "os indivíduos que compõem uma sociedade sentem quase sempre a necessidade de ter antepassados; é esta uma das funções dos grandes homens" (2003, p. 218).

Ainda que seja provável, pelos poucos documentos escritos e a constante ressignificação da memória, torna-se quase impossível afirmar que o Polonês tenha premeditado a narrativa dos episódios espetaculares de sua saga com elementos de modelagem mítica com alguma função inerente, como por exemplo, tomar tais eventos mirabolantes na função de aporte de instrução. No entanto, o sinal indiciário advindo da nomeação que impôs a dois de seus doze filhos, Heitor e Aquiles, sinaliza que esse europeu conhecia e compartilhava a dimensão simbólica da herança deixada pelo passado glorioso da antiguidade grega.

Desse modo, é possível inferir que, talvez o Polonês concatenasse esses episódios com a função de uma Paideia, e assim como os gregos que dispunham desse recurso em relação aos poemas homéricos (VERNANT, 1994), ele retomou essa herança antiga para constituir em seus filhos uma instrução moral que não era possível através da escrita, uma vez que desbravava e "colonizava" uma região que muito pouco conhecia ou carecia da escrita.

Walter J. Ong já considerava que os resultados das formas orais, muitas vezes, não objetivam o puramente estético e nesse sentido,

a representação de uma epopeia oral, por exemplo, também pode servir, simultaneamente como um ato de celebração, como paideia, ou educação para a juventude, como fortalecedor da identidade do grupo, como meio de fazer perdurar o tipo de conhecimento popular - histórico, biológico, zoológico, sociológico, venatório, náutico, religioso e muito mais $(1987, \text { p. 156, tradução nossa })^{10}$

${ }^{10}$ Texto original: "la presentación de una epopeya oral, por ejemplo, también puede servir, 
Claro que, nesse caso, não deixa de ser uma hipótese que se fundamenta, uma vez que, os narradores orais dessa história valorizam e sentem orgulho ao narrarem esses eventos pelos quais passou o seu ancestral.

Em um ambiente rural e ainda, atualmente, de alfabetização precária, onde algumas décadas atrás nem existia escola, não parece forçoso dizer que as narrativas orais, declamadas no seio da família, nos momentos em que os pais se reuniam com os filhos depois da lida diária, geralmente à boca da noite ao redor do fogão a lenha, serviam de mediadoras para transmitir lições de vida e valores fundamentais ao convívio familiar para as novas gerações, ou seja, transmitir seu próprio ethos.

Ora, a retomada do passado dessa comunidade se dá através da saga dessa figura, que em suas constantes retomadas, tornou-se, então, pública. Como Walter J. Ong coloca, a memória oral funciona com maior eficácia quando a referência se detém numa grande figura que representou algo substancial para a comunidade: "a memória oral funciona eficazmente com os grandes personagens cujas proezas sejam gloriosas, memoráveis, e, por último, públicas"11 (1987, p. 73).

O teórico diz ainda que a memória pública engendra essas figuras de dimensões extraordinárias, não por razões românticas ou tonalidade didática, e "sim por motivos muito mais elementares: para organizar a experiência em uma espécie de forma memorável permanente"12 (ONG, 1987, p. 73-74). Nesse âmbito, certas figuras, mesmo humanas, se enaltecem de um patamar de heroicidade, com o qual estabelecem um vínculo dinâmico e permanente com a comunidade, na qual aparecem (ONG, 1987, p. 74).

$\mathrm{O}$ ancestral polonês é em primeira instância um personagem histórico corroborado pelos sinais indiciários que escrutamos. Por outro lado, como nos sinalizam os episódios de sua saga e, como a épica serve de apoio, esse polonês é, acima de tudo, uma figura heroica, que se dobra sobre o patamar de sua própria heroicidade, cujas proezas gloriosas e memoráveis, públicas na memória coletiva e na epopeia Vozes do cerrado não só legitimam, mas organizam essa experiência que, nesse sentido, é estética e,

simultáneamente, como um acto de celebración, como paideia, o educación para la juventud, como fortalecedor de la identidad del grupo, como medio de hacer perdurar todo tipo de conocimiento popular - histórico, biológico, zoológico, sociológico, venatório, náutico, religioso -, y mucho más".

${ }^{11}$ Texto original: "La memoria oral funciona eficazmente com los grandes personajes cuyas proezas sean gloriosas, memorables y, por lo común, públicas".

${ }^{12}$ Texto original: "sino por motivos mucho más elementales: para organizar a experiencia en una especie de forma memorable permanentemente". 
consequentemente, literária.

Voltamos nossa abordagem para o fato de que, numa duração em que na Polônia o Estado político-territorialmente não existia, nação esta subtraída do mapa da Europa e, consequentemente, um não-lugar, um lugar que nem a própria condição de exilado substancialmente materializava o sentimento concreto de um regresso, uma vez que esbarrava numa impossibilidade de voltar para onde, em termos políticos, não existe, o Polonês, inundado, porém, por um sentimento de pertencimento identitário, subverte esse vazio geopolítico e (re)funda nas terras de Pindorama, alguma coisa, que pode ser evocada como sua pátria, sua nação.

Ora, se era difícil o retorno a uma Ítaca que já não existia, depois de atravessar, assim como Odisseu, provações, lutando pela própria vida, o Polonês, astuciosamente, batiza seu latifúndio com uma espécie de saudade retumbada em seu peito, a qual parece um substrato inerente da condição de exílio.

O Polonês ao naufragar-se nesse espaço funda uma Polônia que não é mais o seu país de origem, mas um espaço outro, um alter, que não deixa de possuir um vínculo direto através desse personagem histórico com a sua plataforma europeia, no entanto, consubstanciada por intermédio dessa justaposição de várias culturas que o Brasil moldou e vem modulando ao longo de sua história.

A antiga Fazenda Polônia já não existe unificada em registros. Todavia, continua existindo como referencialidade de uma pertença identitária no coração das centenas de descendentes do ancestral polonês Antonio Rebendoleng Szervinsk ou Antoni Dołęga Czerwiński.

Se a nação polonesa singrou no decorrer de vários anos o desaparecimento de seu Estado em que sobreviveu e atravessou o século do romantismo nesse espaço suspenso da impossibilidade de estatalmente existir, o Polonês, subvertendo essa impossibilidade, e sob a clivagem simbólica do pertencimento identitário e os riscos da ausência e do vazio geopolítico, jamais deixou morrer o seu pertencimento à sua nação.

A Polônia transitou com ele, e $o$ Polonês a refundou, transportando consigo esse sentimento de solidariedade, que à época, agrega e congrega todos os poloneses num espírito análogo de luta pela liberdade. 


\section{REFERÊNCIAS:}

ARISTÓTELES. Poética. Tradução Paulo Pinheiro. São Paulo: Editora 34, 2017.

BÂ, Amadou Hampâté. Amkoullel, o menino fula. Tradução Xina Smith de Vasconcelos. São Paulo: Palas Athena/ Casa das Áfricas, 2003.

CASTORIADIS, Cornelius. A instituição imaginária da sociedade. 5 ed. Tradução Guy Reynaud. Rio de Janeiro: Paz e Terra, 1982.

FARIA, Kiko di. Vozes do cerrado. Brasília: Cartaz, 2009.

FERREIRA, Aurélio Buarque de Holanda. Dicionário Aurélio de Língua Portuguesa. 5 ed. Curitiba: Positivo, 2010.

FOUCAULT, Michel. Nietzsche, a genealogia e a história. In: FOUCAULT, Michel. Microfísica do poder. 16 ed. Tradução Roberto Machado. Rio de Janeiro: Edições Graal, 1979.

HOMERO. Odisseia. Tradução Trajano Vieira. São Paulo: Editora 34, 2011.

KUNDERA, Millan. A ignorância. Tradução Teresa Bulhões Carvalho da Fonseca. São Paulo: Companhia das Letras, 2002.

LE GOFF, Jacques. História. In: LE GOFF, Jacques. História e memória. 5 ed. Tradução Bernardo Leitão et al. Campinas: Unicamp, 2003.

MAGALINSKI, Jan. Contribuição do elemento alienígena nos diversos campos no Estado de Goiás. Disponível em: <https://www.revistas.ufg.br/bgg/article/view/4412/38>. Acesso em 15 de maio de 2020.

MUDROVCIC, Maria Inés. Por que Clio retornou a Minemosine? In: MUDROVCIC, Maria Inés. Cultura política, memória e historiografia. Rio de Janeiro: Editora FGV, 2009.

OLCHA, Antoni. Słowo Wstępne. In: WÓJCIK, Władysław. Moje życie w Brazylii. Ed. LSW (Ludowa Spółdzielnie Wydawnicza). Warszawa, 1961, p. 6-7. Nr.zam. 1157a S-88.

ONG, Walter J. Oralidad y escritura: tecnologías de la palabra. Tradução Angélica Scherp. México: FCE, 1987. 
PINTO, Francisco Eduardo. Cartas de sesmaria. In: GUIMARÃES, Márcia Motta Elione (Org.). Propriedades e disputa: fontes para a história do oitocentos. Guarapuava: Unicentro; Niterói: EDUFF, 2011.

RICOEUR, Paul. A memória, a história, o esquecimento. Tradução: Alain François [et al.]. Campinas, SP: Ed. UNICAMP, 2007.

SALES, Jucelino de. Tessituras de memórias no interior de Goiás: a saga do Polonês Antonio Rebendoleng Szervinsk [des]fiada no tear do imaginário. 2014. 250 f. Dissertação (Mestrado em Literatura) - Instituto de Letras, Departamento de Teoria Literária e Literaturas, Universidade de Brasília, Brasília, 2014.

SIEWIERSKI, Henryk. História da literatura polonesa. Brasília: Ed. UnB/ São Paulo: Imprensa Oficial do Estado, 2000.

VERNANT, Jean Pierre. As origens do pensamento grego. 8 ed. Tradução Isis Borges. Rio de Janeiro: Bertrand Brasil, 1994.

ZUMTHOR, Paul. Introdução à poesia oral. Tradução Jerusa Pires Ferreira et al. São Paulo: Hucitec/EDUC, 1997. 